\title{
The Effects of Integrating Creative and Critical Thinking on Schools Students' Thinking
}

\author{
Ali Salim Rashid Alghafri and Hairul Nizam Bin Ismail
}

\begin{abstract}
The study investigates the effects of thinking on thinking skills (TS) and control groups among 68 standard five Malaysian students at two primary schools. The quasi-experimental design method was employed through TS and control groups. The findings revealed that there were significant differences in post-test scores between these two groups on total scores of the creative thinking, fluency, flexibility advantage for TS group but originality and the scores of thinking performance of science task were no significant. Thus, the study implies that educators, should use thinking skills-based instructional strategy to enhance the levels of creativity and learning among primary schools' students.
\end{abstract}

Index Terms-Creative thinking, critical thinking, science, thinking skills strategy (TS), test of creative thinking (TCT), science task of thinking (STT)

\section{INTRODUCTION}

With the stream of knowledge in our contemporary world, it is important for educators to give learners chances to use their minds [1] by the systematic transformation [2] to apply the knowledge through various ways of thinking, such as creative thinking and critical thinking [3] Psychologists and researchers seek to merge between these two types of thinking [4]-[13] and [14]. Therefore, [4], [9], and Paul and Elder [12] emphasized that creative thinking works consecutively with critical thinking. [4] Also stated that the product of criticism or the evaluation contained generative and creative component.

Norris [15] believed that in order to be able to evaluate their own thinking and to change their thinking behavior, students should know how to apply their prior knowledge and understanding. Consequently, both creative and critical thinking should be involved in the learning and curricula through the context, activities and questions in school subjects, especially mathematics and science [16]. Thus, various studies recommended doing more research on correlation, effect, relationship and interaction of several levels of thinking such as, creative thinking and critical thinking with an overlap in activities and/or curriculum (e.g. [17]). Also, [5] emphasized that much research need to be conducted with different variables, such as age and gender, to study the creative and critical thinking skills. Even though scientific research has shown the importance of creativity, educators are not encouraged to use creative thinking skills upon their learners [18]. Hence, many studies and projects in

Manuscript received September 27, 2013; revised November 30, 2013.

A. S. Alghafri is with the University of Buraimi, P.O. Box 890, P. C. 512 , Sultanate of Oman (e-mail: dr.aalghafri@gmail.com)

Hairul Nizam Bin Ismail is with Universiti Sains Malaysia, 11800, Pulau Penang, Malaysia (e-mail: hairul@usm.my) fields of psychology and education attempt to focus on employing thinking skills on students' learning and/or integration between them [19]-[21]. Specifically, the government of Malaysia strikes to improve its education system, that to provide the students in primary schools with basic skills, with particular regard to thinking skills [22].

Thus, current study attempted to implement both creative and critical thinking as one integrated thinking skills in the science classroom and examines its effectiveness. In other words, it tries to answer the following questions: what are the effects of integrating creative and critical thinking on creative thinking among the participating primary schools students?; and what are the interaction effects between groups and each creative thinking skills in thinking of science task among them?

\section{THINKING SKILLS}

The two common categories of thinking skills are Lower and higher Order Thinking Skills (LOTS\&HOTS) which they represent routine way and perceptive way respectively [23], such as creative and critical thinking [3], [13] and [24].

\section{A. Creative Thinking}

There is no universally accepted definition of the term "creativity" [25]-[27]. There are many definitions of creativity but all of them focus on "the production of something new or original" [28], p. 4. Guilford, indicated that there are no fewer than 120 characteristics of creativity [29].

Guilford has identified four central components of creative thinking skills (divergent thinking) that include: fluency, flexibility, originality and elaboration [30], [31]. Guilford [32], explained these four skills in terms of how they are used as verbal and visual-figural information. Each of them has been measured through standardized tools where many different responses are gathered [33]. In 1966, Torrance developed a series of tests in line with Guilfords' conceptualization of divergent thinking identified as the Torrance Tests of Creative Thinking (TTCT) [34]. For many years, Torrance based TTCT scoring on Guilford's (1956). These include seven (7) verbal sub-tests (activities) and three (3) figural subtests (activities) providing sub-scores for fluency, flexibility, originality and elaboration [31], [35], [36]. However, Torrance had removed the flexibility from later streamlined scoring procedure [37]. According to [18], at the end of the twentieth century creativity research continued to expand, yet today, it is conceptualized as something that anyone can acquire.

\section{B. Critical Thinking}

Theories of critical thinking are varied. One of the theories 
is based on the cognitive scientific perspective utilizing critical thinking as an instruction and the evaluation of teaching and learning [38]. Another relevant theory has developed from the social constructivist perspective, implying that critical thinking is a learned social practice [3]. Other theories describe critical thinking as the reflection, evaluation, and reasoning of both practical and academic requirements [39]. The theory of critical thinking became more and more outreaching over the years. It converted from the generalization to the specific, shifted from the de-contextualized aspect of cognitive skills to social practices and cultural aspects, and changed from explicit teaching methods to an implicit and embedded approach. It is completely directed towards our critical investigation of the world and our own knowledge of it [38], [40], [41].

Therefore, there are different definitions of critical thinking put forward by theorists in the psychology, education, social and other domains [41]-[43], and [44]. Even so, experts agree that critical-thinking behaviors imply an open-minded tendency to analyze, synthesize, and evaluate information in order to solve problems and make resolutions [42], [44]. From the 1990 APA Consensus, [45] emphasized that definition of critical thinking includes the process of interpretation, analysis, evaluation, and inference. However, [46] pointed that critical thinking refers to the reflective and reasonable thinking. According to [47] the study of logic: “... is the study of the methods and principles used to distinguish good (correct) from bad (incorrect) reasoning". (p. 3). Attempting to define what critical thinking is not, Lenburg [48] suggested that critical thinking is different from problem solving, because the latter focuses on a problem to be identified and solved using a reasonable solution.

In addition, from the scientific method perspective, some educators, justify that the idea of critical thinking is a set of complex cognitive abilities inquiring about knowledge in order to use or apply it [38], [49], [50]. The Scientific method is important to be considered in this aspect because of its analytical strength in the testing and application. This method also includes the formulation of hypotheses and theories which are tested and confirmed on the base of observations [51]. According to [45] and [52], consensus critical thinking cognitive skills and sub-skills are summarized as (1) Interpretation, which includes three sub-skills namely categorization, decoding sentences and clarifying meaning. (2) Analysis, which involves examining ideas, identifying arguments and analyzing arguments. (3) Evaluation, which comprises the assessment of claims and arguments. (4) Inference skill, which includes querying evidence, conjecturing alternatives and drawing conclusions. (5) Explanation, in which stating results, justifying procedures and presenting arguments are involved, and (6) Self-regulation, which embodies self-examination and self-correction.

Consequently, the different conceptions and theories of critical thinking result in various tests of critical thinking. As mentioned in the National Postsecondary Education Cooperative [53], there are several critical thinking tests to measure college and university students' critical thinking skills, such as the Academic Profile (A. PROFILE), the
Collegiate Assessment of Academic Proficiency (CAAP), the California Critical Thinking Dispositions Inventory (CCTDI), the CAAP Critical Thinking Assessment Battery (CTAB) and the California Critical Thinking Skills Test (CCTST).

\section{Pertinence between Creative and Critical Thinking}

Several studies have mentioned the relationship between creative thinking and critical thinking. They made them like a divergent and a convergent thinking [6], [7], [10]. [6] stated that: "Whereas creative thinking is divergent, critical thinking is convergent" (p. 35). Paul [54] further elaborates that creative thinking and critical thinking have an intimate relationship with the imaging skill. Creative thinking is also pertinent to irrational or unconscious forces, while critical thinking relates to rational and conscious processes. Hence, all kinds of thinking comprise these two types of thinking in an intimate way [9]-[12].

Moreover, the creative and critical thinking are important for the individuals [7], [12], [13] and the society [7], [13]. According to [55] as cited in [5], creative and critical thinking skills are essential for students. This hypothesis is also supported by Meyers [56], who says that students must learn thinking and reasoning skills to realize their fullest potential in today's society. In view of this, many studies have focused on the combination of critical and creative thinking [4]-[12], and [13], [7] offers a different perspective by saying that: "Even creative thinking enters critical thinking process, so also critical thinking enters creative thinking process".

Many studies evolve around creative and critical thinking. Twin thinking is a particular type of thinking which is related to the nature of both creative and critical thinking. It can be understood as a binary pair: logical versus intuitive, sequential thinking versus insight thinking, analysis versus synthetic, convergent versus divergent, evaluative versus generative, and reduction and division versus integration [4], [57]. Some researchers stated that creativity is a part of being critical. While the argument is considered rational, there are others who state that being critical is part of creativity [4]. Moore, McCann, and McCann [58] emphasized the importance of linking the two together: "it should never be forgotten that creative and critical thinking are two sides of the same coins: one is of little use without the other" (p. 361).

Ref. [59] suggested a model of creative and critical thinking in regards to the sequential phases of scientific creation found in the literature of Koestler's (1964) and Wallas (1926). Those phases are known as preparation, incubation, illumination and verification. Lawson's study [59] showed that the creative and thinking skills are two kinds of thinking which can work together in order to judge and generate ideas in a new situation. Even though the two appear to be different, they are seen as unitary, inseparable, and integrated. In order to produce higher order thinking, the mind should simultaneously assess and produce, judge and generate thoughts. They also require imagination and intellect. Therefore, both the intellectual creation and critical judgment have a reciprocal logic. There is a close interrelation between the intellectual production and the progressing critique of that making [12]. 


\section{IMPLEMENTING CREATIVE AND CRITICAL THINKING IN CURRICULUM}

Thinking skills are overlapping and connected in complex ways due to many theories which outline that the thinking skills are mutually supportive and interdependent [7]. This means that each thinking skill cannot be taught at once, but only by progress and interpenetration in a spiral learning and teaching process. In addition, thinking skills are applied in sophisticated methods and in growing complex context [60]. One of students' thinking skills is the scientific skills, which should be enhanced by the science subject. The scientific skills are beneficial to face new situations and make hypotheses; also to interpret the basic scientific knowledge [61].

Moreover, according to recommendations of Faux's results [17], there was a need to build and design the curriculum for all levels of students' achievements in several thinking skills, because hardly everyone are able to make all students become the most creative thinkers. Likewise, Paul and Elder [12] stated that all truly excellent thinking combines both creative and critical thinking. Therefore, many studies asserted to investigate the relationship between creative and critical thinking by either integrating and not integrating them into the curriculum. Lawson's study of merging creative and critical thinking together in the curriculum [59] showed that the performance of 514 non-science majored students has improved. This is enough evidence to suggest that students perform better in this kind of curriculum design.

Consequently, present TS study was made to be suitable for all levels of students and it includes various thinking skills of creativity and critical thinking via science curricula regarding to the importance of the science subject in the schools, specifically the learning of science subjects with the use of thinking skills. The National Science Education Standards (NRC, 1996) stated the main principles of the notion that science is for all students and that curriculum content should be designed to develop the students' brain, thinking, interests, emotion, abilities, understandings, experiences, and knowledge.

Thus, science subject is important for students and for everyone in order to be familiar about nature, body, and materials of the world in general. Moreover, it includes several scientific disciplines, like physics, biology and chemistry. In addition, it is related to other subjects, such as mathematics. Therefore, science is important to be present in a curriculum which includes a good learning ways to attain a scientific knowledge [61]. In addition, the science is important discipline for technology [62]. Hence, the issues of science, such as students thinking and learning of science; methods and strategies teaching of science; and science curriculum for developing and improving a knowledge of science to use them in several purposes of life should be investigated [61]. Accordingly, Malaysia's 2020 vision stated that science is an important subject for development [63].

\section{A. Approaches of Integrating Thinking Skills in the Curriculum}

Many researchers agree that integrating thinking skills in the curriculum will help students enhancing their thinking abilities and their higher order skills [21], [60], [64], [65]. It is also believed that thinking skills should not be taught in isolation, but instead be integrated across the curriculum [21], [60], [64]-[67]. Accordingly, McPeck's [49] believes that critical thinking is one kind of thinking that cannot be done in vacuum. It needs knowledge of a subject matter because, in the context of said subject matter, critical thinking means thinking about $\mathrm{X}$ (defined as the subject matter). Consequently, this condition includes other kinds of thinking such as the creative thinking. In contrast, [38] states that it is important to view the logical components of critical thinking outside the context of a subject ignoring the pragmatic or contextual components. Hence, the findings of a study conducted by Faux in 1992 [17] have several implications for educators responsible for the teaching of creative and critical thinking skills. One major implication is that working with higher order thinking needs more time and practice to include several thinking activities into an already overloaded curriculum that may provide skills to the students through the learning.

Therefore, many articles and studies have demonstrated that different types of thinking, such as creative thinking and critical thinking, can be taught [4]. According to Prawat [68] and Weinstein [60], there are three approaches to thinking skills instruction. First, the separate approach involves the teaching of several thinking skills isolated from the content of a subject matter [10]. The thinking skills in this approach are firstly identified, and are taught as a separate course or subject. Students can learn to apply separate thinking skills in different subjects and situations. Second, the partial embodiment approach includes high level thinking skills which are introduced by various challenging questions and activities without implicating the teaching of thinking skills in a subject. Finally, the implication approach, on the other hand, incorporates the teaching and the identification of thinking skills within the context of a subject matter. In this kind of approach, students can apply various thinking skills immediately in the particular subject matter while they are learning. Hence, they are able to use the skills in meaningful context, real life context and understand those skills better. Prawat [68] and Weinstein [60] stated that the implication approach is the most effective to teach thinking skills in any curriculum. Moreover, it is beneficial to use thinking skills to enhance whatever type of curriculum that is taught.

Supporting this, O'Brien, [69] stated that the science curriculum should include thinking skills in order to help students using their skills and thinking using thinking strategies because children's knowledge in age between 7-12 is more filtered by mature steps of thinking and constructing the knowledge [70]. Moreover, according to Talib, Su Luan, Azhar, and Abdullah [63], good achievement and performance in the learning of science are not dependant on the teaching only, but also on other factors such as students' skills and ability. Hence, should primary school students understand the scientific knowledge as well as the use of thinking skills in order to master the essentials in scientific disciplines, that becomes by science curriculum [71].

Consistently, the Ministry of Education in Malaysia is resolute to continue develop science curricula to attain 
scientific objectives. Hence, the main aims of the Malaysian science curriculum are to provide students with the means to acquire scientific knowledge and skills, develop thinking skills and thinking strategies, and also applying and use said knowledge and skills in everyday life [72]. In light of the previous considerations, the current study chooses the third type of learning thinking approach being an implicational approach to thinking skills (TS), in order to teach thinking through a curriculum of Year 5 science subject in terms of skills of creative and critical thinking. That because science subject of standard five contains topics which are suitable to practice thinking skills through them. For more details, science subject curriculum of standard five contains two main themes. First theme is called investigating living things which includes microorganisms unit, survival of the species unit and food chain and food web unit. Whereas, the second them is titled investigating force and energy which involves energy, electricity, light, heat.

\section{B. Applying Creative and Critical Skills in TS strategy}

According to [73], creative and critical learning are necessary skills for innovation. Guilford identifies three central components of creative thinking skills (divergent thinking) namely fluency, flexibility, originality [30], [31], [34] and [36]. These three thinking skills are chosen for the purpose of this study. Likewise, the current study uses four skills of critical which are taken from APA critical skills. According to the APA consensus [45], [52], critical thinking cognitive skills and sub-skills can be identified as 1) Interpretation which includes three sub-skills namely categorization, decoding sentences and clarifying meaning, 2) Analysis which involves examining ideas, identifying arguments and analyzing arguments. 3) Evaluation which comprises assessing claims and assessing arguments, and 4) Inference skill including querying evidence, conjecturing alternatives and drawing conclusions.

As mentioned earlier, both creative and critical thinking interpenetrate each other. According to [4], they function in an alternating step without constrain. For example, when solving a problem, logical and analytical thinking (critical thinking) will occur first. This is followed by the generation and suspension of a large number of ideas or judgments (creative thinking). Next, those ideas or judgments will be evaluated (critical thinking) in order to get the best solution.

In view of this, the TS will take into account both the creative and critical thinking as one dynamic and reciprocal thinking strategy. In reference to [4], various studies have outlined the following processes in both creative and critical thinking: generating ideas, synthesizing to create, supplying imaginative constructs, questioning assumptions and discarding beliefs, and also appeal to reasons, reasonable, reflective, judgment, dialectical, adheres to normal standards and criteria. Moreover, current studies and Lawson's study share some similarities in the integration of kinds of thinking, creative and critical thinking, and the application of thinking skills in curriculum that either in TS strategy of current study. Nevertheless, they differ in the methodologies and the study sample. Present study attempted to combine creative thinking and critical thinking together in one strategy which is called TS strategy via curriculum. As mentioned earlier, the current study mentioned that strategy connected creative and critical thinking to construct an innovative thinking strategy which is known as Thinking Skills (TS). The TS strategy briefly introduces the students to thinking skills. It covers critical and creative thinking skills specifically, as shown in Fig. 1.

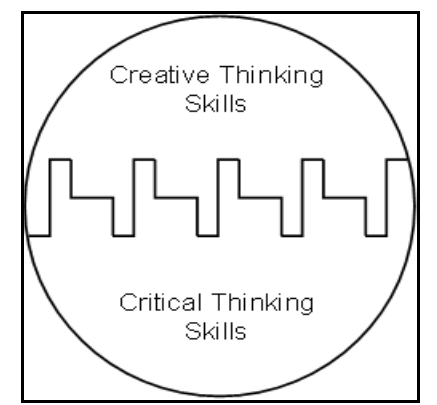

Fig. 1. Components of thinking skills (TS) strategy

Fig. 1 introduces two types of thinking (creative and critical thinking skills) as interactive elements. These skills do not function separately but they interact with one another. This process can be seen as a strategy of thinking that is based on creative and critical thinking. In conclusion, the Thinking Skills (TS) is defined as a strategic thinking involving interaction between creative and critical thinking skills that to engages individual's (one's) thinking during the activity in order to get an individual's (one's) thinking achievement.

Consequently, creative and critical thinking skills implicated into science unit of standard five in strategy of TS. This strategy was suggested for students and teachers to be applied in a classroom by merging thinking skills through curriculum and using a meaningful context, as well as a complex cognitive questions and activities that are open-ended and call high-level thinking. Besides that, the students should apply thinking skills directly to the science subject through their learning. Also, they have to implement their skills in a meaningful context using deeply thinking by using creative thinking skills (fluency, flexibility \& originality) and critical thinking skills (interpretation, analysis, evaluation \& inference).

\section{Methodology}

Data were collected from 68 standard five students whom enrolled in school during the period of May until July 2010. A total of 32 students were placed in the TS group and the remaining 36 students in the control group and they were selected randomly from two different primary schools. The syllabus of the TS strategy group was designed to consider the thinking skills via science subject of primary curriculum of year five. Thereby, to employing the syllabus in TS strategy, there are three tools of current studies' strategies, namely brochure of the strategy, the implementation guide, and the lessons plan. When the teacher in TS group wants to apply the strategy upon the students, he/she must know that these tools are helpful to implicate the thinking skills in science topics of Malaysian science subject curriculum as well as in the lesson plans of "yearly scheme of work" of Education Department. Therefore, the teachers in this 
strategies have to prepare for science topics in parallel way of integrate them together.

Moreover, teacher and students' roles in thinking skills strategy. The TS group should implicate the thinking ways, steps and stages in unintended way into activities which related to each science topic. Also, in TS group, the students will be asked several thinking questions for each science topic.

In the study, the researcher prepared the TCT and STT. Test of Creative Thinking (TCT) is paper and pencil form test was employed in science subject as the verbal creative test for measuring the following skills: fluency, flexibility, originality. These items include several kinds of activities related to science subject. However, Science Task of Thinking (STT) was developed in the form of paper and pencil test for all participating students. Images in STT task was made according to the types of thinking. The thinking task items consisted of creative thinking pictures and critical thinking pictures. The science task of thinking measures skills of creative and critical thinking by displaying pictures. Thus, this task portrayed two types of thinking pictures (creative and critical) and each type has eight different questions.

These test and task were administered to determine the thinking skills of students before and after the intervention. In order to acquire the reliability between study instruments, Cronbach alpha and Pearson correlation were used at $\alpha .05$ level. The Cronbach alpha value of all test and task were significant. TCT is 0.79 , STT (Form A) is 0.81 , STT (Form B) is 0.86 . The reliability between form A and B of thinking tasks are significant in Pearson correlation. The reliability of the two instruments used in the present study was checked through a test retest for one month. All the correlations are significant.

\section{RESULTS}

In order to determine whether there is a significant difference between the creative thinking, and thinking in science task of the TS group and control group before and after the treatment, descriptive statistics, such as means, standard deviations, two ways Analysis of Covariance (ANCOVA), two way Multivariate analysis of Covariance (MANCOVA) test and LSD statistically method were used at .05 alpha level.

\section{A. The Creative Thinking Results}

The average mean of the posttest creative thinking scores for students in the TS strategy group $(N=32, M=11.34, S D=$ $3.92)$ is higher than that of the control group $(N=36, M=8.31$, $S D=3.41)$. The result of ANCOVA revealed a significant difference between the groups' total posttest creative thinking scores $(F=9.669 ; \rho .05=0.003)$. However, Levene's test showed a significant difference $(F=4.035$; $\rho .05=0.049)$. This result indicated that the assumption of homogeneity of variances has been violated. The results of all the tests are reported in Table I.

TABLE I: ANCOVA ReSUlts FOR THE DifFERENCE BETWEen StUdENTS' PERFORMANCES IN CREATIVE THINKING TESTS

\begin{tabular}{|c|c|c|c|c|c|c|c|}
\hline $\begin{array}{l}\text { Levene's Test of } \\
\text { Creative Posttest }\end{array}$ & Source & $\begin{array}{l}\text { Type III Sum of } \\
\text { Squares of Squares }\end{array}$ & $\mathrm{df}$ & $\begin{array}{l}\text { Mean } \\
\text { Square }\end{array}$ & $F$ & Sig. & $\begin{array}{l}\text { Partial Eta } \\
\text { Squared }\end{array}$ \\
\hline \multirow{7}{*}{$\begin{array}{l}F=4.035 \\
\text { df } 1=1 \\
\text { df } 2=66 \\
\text { Sig. }=0.049\end{array}$} & Corrected Model & $213.96 \mathrm{a}$ & 2 & 106.98 & 8.42 & 0.00 & 0.206 \\
\hline & Intercept & 640.62 & 1 & 640.62 & 50.43 & 0.00 & 0.437 \\
\hline & Group & 122.82 & 1 & 122.82 & 9.67 & 0.00 & 0.129 \\
\hline & Pre Creative & 57.99 & 1 & 57.992 & 4.57 & 0.03 & 0.066 \\
\hline & Error & 825.66 & 65 & 12.702 & & & \\
\hline & Total & 7487.16 & 68 & & & & \\
\hline & Corrected Total & 1039.62 & 67 & & & & \\
\hline
\end{tabular}

a R Squared $=0.206$ (Adjusted R Squared $=0.181$ )

TABLE II: MEAN AND StANDARD DEVIATION OF CREATIVE THINKING SKILLS OF THE POST TEST IN EACH GROUP
\begin{tabular}{|l|l|l|l|l|l|}
\hline \multirow{3}{*}{ Test Type } & Variables & Group & Mean & $\begin{array}{l}\text { Standard } \\
\text { Deviation }\end{array}$ & $N$ \\
\hline \multirow{3}{*}{ Posttest } & \multirow{2}{*}{ Fluency } & TS & 6.3884 & 2.4512 & 32 \\
\cline { 2 - 7 } & \multirow{2}{*}{ Flexibility } & Control & 3.853 & 1.5171 & 36 \\
\cline { 2 - 6 } & TS & 2.3661 & 0.7063 & 32 \\
\cline { 2 - 6 } & Originality & TS & 2.6295 & 1.6328 & 32 \\
\hline & & Control & 1.9127 & 0.4116 & 36 \\
\hline
\end{tabular}

Since the total scores of the two groups in the creative thinking tests were significantly different, the LSD post hoc test was used to determine the actual pairs. The finding indicated a significant difference $(\rho .05=0.003)$ between the TS and control groups in favor of the TS group (mean difference $=2.729$, std. error $=0.878$ ). Therefore, the TS

The result showed that Levene's test of equality of error students were classified as the higher-performance group in the post TCT.

On the other hand, the present study used the means of the posttest scores of three dependent variables (fluency, flexibility, and originality) in the MANCOVA test to compare the two groups (TS and control) (see Table II). variances was significant for fluency and flexibility skills 
(fluency: $F=17.363, \rho .05=0.000$; flexibility: $F=15.742$, $\rho .05=0.000 ;$ originality: $F=0.051, \rho>0.05=0.822)$. This result shows that the skill levels among students are not equal except in originality. Box's test is also significant (Box's M = $41.840, F=6.627, \rho .05=0.000)$. This finding is finally determined by the tests of between-subject effects (fluency: $F=27.012, \rho .05=0.000$; flexibility: $F=8.939, \rho .05=0.004$; originality: $F=0.051, \rho .05=0.821$ ) and the results of overall MANCOVA shown in Table II and Table II, respectively.

\begin{tabular}{|l|l|l|l|l|l|l|}
\hline \multicolumn{2}{|c|}{ TABLE III: MULTIVARIATE TESTS OF DIFFERENCES BETWEEN CREATIVE THINKING SKILLS } \\
\hline $\begin{array}{l}\text { Value of Wilks' } \\
\text { Lambda }\end{array}$ & $F$ & Hypothesis df & Error df & SIG. & $\begin{array}{l}\text { Eta } \\
\text { Squared }\end{array}$ \\
\hline Intercept & 0.407 & $29.682 \mathrm{a}$ & 3.000 & 61.00 & 0.00 & 0.593 \\
\hline Group & 0.628 & $12.026 \mathrm{a}$ & 3.000 & 61.00 & 0.00 & 0.372 \\
\hline Pre Fluency & 0.950 & $1.065 \mathrm{a}$ & 3.000 & 61.00 & 0.37 & 0.050 \\
\hline Pre Flexibility & 0.903 & $2.165 \mathrm{a}$ & 3.000 & 61.00 & 0.10 & 0.096 \\
\hline Pre Originality & 0.922 & $1.719 \mathrm{a}$ & 3.000 & 61.00 & 0.17 & 0.078 \\
\hline
\end{tabular}

aExact statistic

TABLE IV: ANCOVA TEST FOR DIFFERENCE BETWEEN STUDY GROUPS IN THINKING PERFORMANCE IN SCIENCE TASKS

\begin{tabular}{|c|c|c|c|c|c|c|c|}
\hline $\begin{array}{l}\text { Levene's Test of } \\
\text { Thinking Posttest }\end{array}$ & Source & $\begin{array}{l}\text { Type III Sum of } \\
\text { Squares of Squares }\end{array}$ & $\mathrm{df}$ & $\begin{array}{l}\text { Mean } \\
\text { Square }\end{array}$ & $F$ & Sig. & $\begin{array}{l}\text { Partial Eta } \\
\text { Squared }\end{array}$ \\
\hline \multirow{7}{*}{$\begin{array}{l}F=4.478 \\
\text { df } 1=1 \\
\text { df } 2=66 \\
\text { Sig. }=0.038\end{array}$} & Corrected Model & $0.578 \mathrm{a}$ & 2 & 0.289 & 4.437 & 0.02 & 0.120 \\
\hline & Intercept & 0.773 & 1 & 0.773 & 11.860 & 0.00 & 0.154 \\
\hline & Group & 0.030 & 1 & 0.030 & 0.453 & 0.50 & 0.007 \\
\hline & Pre Thinking & 0.557 & 1 & 0.557 & 8.552 & 0.01 & 0.116 \\
\hline & Error & 4.235 & 65 & 0.065 & & & \\
\hline & Total & 142.469 & 68 & & & & \\
\hline & Corrected Total & 4.813 & 67 & & & & \\
\hline
\end{tabular}

The result of Wilks' Lambda $\lambda$ of the (MANCOVA) test indicated significant differences $(\rho .05=0.000)$ between the two groups in post-TCT skills $(\lambda=0.628, F=12.026, \rho .05=$ $0.000)$. This result proves that the scores of the study groups were different (see Table III). Multivariate $\eta^{2}=.372$ indicates the effect size, meaning that most of the $37 \%$ variation in pre-test creative thinking skills is attributed to the differences between the students' groups. To determine the direction of the significant differences between the groups, the LSD test was used.

The LSD test indicated significant difference $(\rho .05=0.000)$ in fluency skills between the TS $(M=6.39, S D=2.45)$ and control $(M=3.85, S D=1.51)$ groups benefiting the TS group and showed a significant difference $(\rho .05=0.004)$ in flexibility between the TS $(M=2.37, S D=0.71)$ and control $(M=1.91, S D=0.41)$ groups with gains for the former (TS group), whereas in originality $(\rho>.05=0.821 ; T S: M=2.63$, $S D=1.63$; control: $M=2.58, S D=1.84)$. Thus, the TS group showed higher performance in posttest fluency and flexibility but no difference in originality.

\section{B. Thinking results of Science Tasks}

The average mean scores of the TS strategy group in post-task thinking in science $(N=32, M=1.44, S D=0.31)$ were higher than those of the control strategy group $(N=36$, $M=1.41, S D=0.226$ ). The results of ANCOVA showed no significant difference between the groups in posttest general thinking in science tasks $(F=4.453, \rho>.05=0.503)$. However, Levene's test $(F=4.478 ; \rho .05=0.038)$ showed that the scores of the studied groups were different (see Table IV). Thus, the students in both groups were same in the post STT results.

\section{DISCUSSION}

The results show that the main objective of the study which was to improve students' learning through enhancing their creative thinking and performances of science task (thinking) is met. The results revealed that there was a significant difference between the TS and control groups with the advantage for TS strategy except in originality and science task achievement. One possible interpretation of the result is that TS strategy had intensive activities of creative thinking during the science classroom, while students in the control group did not have. As Nichols, Thomson, Wolfe and Merritt [74] believed that the more intensive activities improve the higher order of thinking skills of primary grade students. Another possible explanation is that the different learning environment between TS and control groups might have permitted the TS students to be more focused on new idea as compared to TS students. As such, there were also some differences in terms of the instructions, syllabus, and thinking strategies. Therefore, the learning environment could have affected the students' thinking style and the science thinking. The findings showed that there were significant differences in fluency in respect to experimental group comparing with control group is due to the fact that students felt free to generate more ideas for the activities in 
TS groups, because the teachers in both groups may have given them the chance to generate new ideas as long as they practiced the creativity activities and adapted in with the activity. According Herbert, [35] stated, many studies skipped flexibility because it correlates highly with fluency. For that reason, students of the experimental group have scored higher on flexibility and fluency. The one interpretation of the students have close performance in originality and thinking of science task is that the regular students in standard five are around eleven age, so usually are more able to use the logical thinking in this age [75] that based on the critical thinking because it is recognized as a logic thinking [4], [9], [38]. Additionally, the students in both groups might be were careless in the task when they felt that the tasks were not related to the school curriculum. Thus, they did not concentrate or they did not focus on their attention to generate new, unique solutions during the activities.

\section{CONCLUSION}

This study has contributed to integrate creative thinking with critical thinking. The managed to support thinking and learning of the primary students by implicating the skills of thinking in a learning strategy. This was made to be suitable for all students' levels. In short, the study contributed to; (i) identify the accurate information of the level of the students' thinking, (ii) suggest an effective design of the syllabus for standard 5 science subject to be used in the primary schools, and (iii) provide the information regarding the advantage of the TS in enhancing students learning and thinking.

\section{REFERENCES}

[1] D. Gough, "Thinking about thinking," Research Roundup, vol. 7, no. 2, 1991.

[2] K. Holyoak and R. Morrison, "Thinking and Reasoning a reader's guide," in K. J. Holyoak and R. G. Morrison (Eds.), The Cambridge Handbook of Thinking and Reasoning, New York: Cambridge University press, pp.1-7, 2005.

[3] A. S. R. Alghafri, The Factors which Effects in Selections of (11) Grade Students for Subjects of Academic Plan in General Education in Sultanate of Oman, Ministry of Education, Sultanate of Oman, 2008.

[4] S. Bailin, "Epilogue Problems in Conceptualizing Good Thinking," The American Behavioral Scientist (1986-1994), vol. 37, no. 1, pp. 156-164, 1993

[5] M. Baker and R. Rudd, "Relationships between Critical and Creative Thinking," Journal of Southern Agricultural Education Research, vol. 51, no. 1, pp. 173-188, 2001.

[6] B. K. Beyer, Practical Strategies for the Teaching of Thinking, Boston MA: Allyn and Bacon, Inc, 1987.

[7] B. D. Bleedorn, "Introduction toward an integration of creative and critical thinking," The American Behavioral Scientist (1986-1994), vol. 37, no. 1, pp. 10-20, 1993.

[8] B. Coe, "The heart of the senior year," Montessori Life, vol. 19, no. 4, pp. 22-25, 2007.

[9] L. Elder and R. Paul, "Critical thinking: The nature of critical and creative thought," Journal of Developmental Education, vol. 30, no. 3, pp. 36-37, 2007.

[10] A. Johnson, "How to use thinking skills to differentiate curricula for gifted and highly creative students," Gifted Child Today, vol. 24, no. 4, pp. 58-63, 2001 .

[11] P. A. Murphy, "Relationship between creativity, tolerance of ambiguity, and critical thinking among undergraduate nursing students," Ph.D., Adelphi University, 1999.

[12] R. Paul and L. Elder, "Critical thinking: the nature of critical and creative thought," Journal of Developmental Education, vol. 30, no. 2, $34-35,2006$
[13] S. C. Yang and W. C. Lin, "The relationship among creative, critical thinking and thinking styles in Taiwan high school students," Journal of Instructional Psychology, vol. 31, no. 1, pp. 33-45, 2004.

[14] A. Zimmerman, M. Lima, and A. D. Christy, "Student-centered learning activities," Resource, vol. 10, no. 8, pp. 9-10, 2003.

[15] S. P. Norris, "Synthesis of research on critical thinking," Educational Leadership, vol. 42, no. 8, pp. 40-46, 1985.

[16] L. D. Edward and E. K. David, American educators encyclopedia, Westport, CT: Green Wood Press, 1982.

[17] B. J. Faux, "An analysis of the interaction of critical thinking, creative thinking, and intelligence with problem-solving," Ed. D., Temple University, 1992.

[18] T. H. Smith, "Creativity research review: Some lessons for higher education," Peer Review, vol. 8, no. 2, pp. 23-28, 2006.

[19] A. L. Costa, "Developing minds: A resource book for teaching thinking. Revised Edition," Alexandria, VA: Association of Supervision and Curriculum Development, vol. 1, 1991.

[20] E. Geist and J. Hohn, "Encouraging creativity in the face of administrative convenience: How our schools discourage divergent thinking," Education, vol. 130, no. 1, pp. 141-150, 2009.

[21] G. E. Westwood, "Integrating thinking skills into the third grade social studies curriculum," ED. D, Nova University, 1993.

[22] N. Lee, "Developing and validating an instrument to assess performance of public sector organisations: a case study of Malaysian schools," Measuring Business Excellence, vol. 12, no. 3, pp. 56-75, 2008.

[23] M. H. Chen, P. J. Gualberto, C. L. Tameta, and D. L. Salle, "The development of metacognitive reading awareness inventory," TESOL Journal, no. 1, pp. 43-57, 2009.

[24] S. D. ohnson, "A framework for technology education curricula which emphasizes intellectual processes," Journal of Technology Education, vol. 3, no. 2, 1992.

[25] R. R. Daniels, "Fostering creative behavior attitudes among university men," The Creative Child and Adult Quarterly, vol. 12, no, 3, pp. 162-67, 1987.

[26] H. B. Parkhurst, "Confusion, lack of consensus, and the definition of creativity as a construct," Journal of Creative Behavior, vol. 33, first quarter, pp. 1-21, 1999.

[27] D. N. Perkins, "Creativity by design," Educational Leadership, vol. 42, September, pp. 18-24, 1984

[28] E. P. Torrance, Creativity, N. W. Washington: National Education Association of the United States, 1963.

[29] H. Alder, CQ Boost Your Creative Intelligence Powerful Ways to Improve your Creativity Quotient, London: Kogan Page, 2002.

[30] F. S. McIntyre, R. E. Hite, and M. K. Rickard, "Individual characteristics and creativity in the marketing classroom: Exploratory insights," Journal of Marketing Education, vol. 25, no. 2, pp. 143-150, 2003.

[31] D. C. Roland, "Effects of open-ended design experiences upon divergent thinking abilities of element school students," Illinois State University, pp. 306, 1983.

[32] J. P. Guilford, The nature of human intelligence, New York: McGrawHill, 1967.

[33] J. P. Guilford, The analysis of intelligence, New York: McGrawHill, 1971.

[34] E. P. Torrance, Torrance tests of creative thinking, Bensenville, I11: Scholastic Testing Service, Inc, 1966.

[35] B. Cramond, J. M. Morgan D. Bandalos, and L. Zuo, "A report on the 40-year follow-up of the Torrance tests of creative thinking: Alive and well in the new millennium," The Gifted Child Quarterly, vol. 49, no. 4, pp. 283-294, 2005

[36] E. P. Torrance, Norms-Technical Manual: Torrance Tests of Creative Thinking, Lexington, MA: Ginn \& Company, 1974.

[37] D. Wechsler, The Wechsler Intelligence Scale for Children, New York: Psychological Corp, 1949.

[38] R. H. Ennis, "A concept of critical thinking," Harvard Educational Review, no. 32, pp. 81- 111, 1962.

[39] S. P. Norris and R. H. Ennis, Evaluating Critical Thinking: The Practitioners' Guide to Teaching Thinking Series, Pacific Grove, CA: Critical Thinking Press and Software, 1989.

[40] D. Atkinson, "A Critical approach to critical thinking in TESOL," TESOL Quarterly, vol. 31, no. 1, pp. 71-94, 1997.

[41] A. Evers, "Does discipline matter? Pedagogical approaches to critical thinking in English for academic purposes and economics," Online Submission, 2007.

[42] F. A .Dixon, K. A. Prater, and H. M. Vine, "Teaching to their thinking: A strategy to meet the critical-thinking needs of gifted students," Journal for the Education of the Gifted, vol. 28, no. 4, pp. 56-76, 2004. 
[43] P. Hynes and J. Bennett, "About critical thinking," Dynamics, vol. 15 , no. 3, pp. 26-29, 2004.

[44] J. G. Kurfiss, "Critical thinking: Theory, research, practice, and possibilities" Association for the Study of Higher Education, Washington, DC, 1988.

[45] P. A. Facione, "Critical thinking: A statement of expert consensus for purposes of educational assessment and instruction," The Delphi Report: Research findings and recommendations prepared for the American Philosophical Association. Project Director, 1990.

[46] R. H. Ennis, "A logical basis for measuring critical thinking skills," Educational Leadership, vol. 43, no.2, pp. 44-48, 1985.

[47] I. M. Copi, Introduction to logic, New York: Macmillan, 1986.

[48] C. B. Lenburg, "Confusing facets of critical thinking," Tennessee Nurse, vol. 60, no. 5, pp. 11-13, 1997.

[49] J. E. McPeck, Critical Thinking and Education, New York: St Martin's Press, 1981.

[50] H. Siegel, Educating Reason: Rationality, Critical Thinking and Education, New York: Routledge, 1988.

[51] P. Ikuenobe, "Teaching and assessing critical thinking abilities as outcomes in an informal logic course," Teaching in Higher Education, vol. 6, no. 1, pp. 19-32, 2001.

[52] N. C. Facione and P. A. Facione, "Externalizing the critical thinking in knowledge development and clinical judgment," Nursing Outlook, vol. 44, no. 3, pp. 129-136, 1996.

[53] National Postsecondary Education Cooperative, "The NPEC sourcebook on assessment: Definitions and assessment methods for critical thinking, problem solving, and writing," National Center for Education Statistics, Office of Educational Research and Improvement, U.S. Department of Education, Washington, DC 20006, vol. 1, 1992.

[54] R. Paul, "Critical thinking: What every person needs to survive in a rapidly changing world," CA: Foundation for Critical Thinking, 1993.

[55] L. D. Crane, "Unlocking the brain's two powerful learning systems," Journal of Southern Agricultural Education Research, vol. 51, no. 1, pp. $173-188,1983$.

[56] C. Meyers, Teaching Students to Think Critically, San Francisco, CA: Jossey-Bass Inc. Publishers, 1986.

[57] R. Jevning and M. C. Biedebach, "The problem of creative thought: A psycho physiological technique for higher creativity," The American Behavioral Scientist (1986-1994), vol. 37, no. 1, pp. 79-14, 1993.

[58] D. W. Moore, R. A. Bhadelia, R. L. Billings, C. Fulwiler, K. M. Heilman, K. M. Rood, and D. A. Gansler, "Hemispheric connectivity and the visual-spatial divergent-thinking component of creativity," Brain and Cognition, vol. 70, no.3, pp. 267-72, 2009.

[59] A. E. Lawson, "Promoting creative and critical thinking skills in college biology," Bioscene, vol. 27, no. 1, pp. 13-24, 2001. EJ630113.

[60] M. Weinstein, "Integrating thinking skills into the schools," Resource Publication, vol. 1, no. 3, 1988, ED352328.

[61] J. Sears and P. Sorenson, Issues in Science Teaching, New York, NY: Routledge Falmer, Taylor \& Francis Group, 2005.

[62] S. Rowlands, "The crisis in science education and the need to enculturate all learners in science," in Petroselli, C. L. (editor), Science Education Issues and Developments, pp. 95-112, New York: Nova Science Publishers, Inc, 2008.

[63] O. Talib, W. S. Luan, S. C. Azhar, and N. Abdullah, "Uncovering Malaysian students' motivation to learning science," European Journal of Social Sciences, vol. 8, no. 2, pp. 266-276, 2009.
[64] J. D. Kozlovsky, "Integrating thinking skills and mastery learning in Baltimore county," Educational Leadership, vol. 47, no. 5, pp. 6, 1990.

[65] C. C. Shaw, "Integrating thinking skills software into the curriculum," Paper presented at the annual international conference of the national council of states on in-service education, Nashville, TN, pp. 21-25, November, 1986.

[66] B. K. Beyer and J. D. Backes, "Integrating thinking skills into the curriculum," Principal, vol. 69, no. 3, pp. 18-21, 1990.

[67] L. E. Lopez and A. Sanchez, "A model for integrating thinking skills in the curriculum," presented at the annual international conference on critical thinking and educational reform, 1992.

[68] R. Prawat, "Embedded thinking skill instruction in subject matter instruction," Association of Supervision and Curriculum Development, vol. 1, pp. 185-186, 1991.

[69] P. O'Brien, "A challenging curriculum for the more able pupil," Issues in Science Teaching, New York, NY: Routledge Falmer, pp. 183-194, 2005.

[70] J. Piaget, The Origin of Intelligence in Children, New York: Norton, 1963.

[71] J. Roden, "Primary science: a second-class core subject?" Issues in Science Teaching, New York, NY: Routledge Falmer, Taylor and Francis Group, pp. 31-40, 2005.

[72] Ministry of Education Malaysia, Integrated Curriculum for Secondary Schools, Curriculum Specifications, Curriculum Development Centre, Kuala Lumpur, 2006.

[73] W. H. A. Johnson and J. W. Weiss, "A stage model of education and innovation type in China: the paradox of the dragon," Journal of Technology Management in China, vol. 3, no. 1, pp. 66-81, 2008.

[74] J. Nichols, S. Thomson, M. Wolfe, and D. Merritt, Primary Education Thinking Skills, Marion, Illinois: Pieces of Learning, 1997.

[75] J. Piaget, Structuralism, London: Routledge and Kegan Paul, 1971.

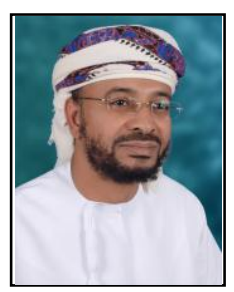

Ali S. R. Alghafri was born on June 1, 1969 Alburaimi State, Sultanate of Oman. He has got married. He got his Ph.D. on Educational Psychology, from Universiti Sains Malaysia (USM), Penang, Malaysia. By the grace of Allah, he got Universiti Sains Malaysia PERDANA Postgraduate Research Grant of the best project which would last 12 months (April 2010-March 2011). He also got Universiti Sains Malaysia (USM) Fellowship award during PhD. program, from 01/07/alim Rashi2008 to 31/12/2010. He also got Ministry of Education Scholarship award during Master program, from 01/09/2002 to 31/08/2004, because he accomplished the third best student (Grade A) in Advantage Diploma of Educational Supervision. Ali S d Alghafri got the excellent employer at the Ministry level for academic year 2013, in 31 May 2013, in Ministry of Education, Sultanate of Oman and the best research in Ministry of Education in year 2007, research competition of Ministry staff, Sultanate of Oman. He was the director of Student Engagement \& Academic Advisement Center at University of Buraimi in Sultanate of Oman. And head of applied science section since academic year of 2012/2013 as well as the Directorate General of Education at Alburaimi governorate. He had experience in teaching several courses in specialization area for bachelor, professional diploma and master students. 